\title{
Effect of Fractions of Alcoholic Extract of Moringa oleifera Lam. Bark on Dexamethasone induced Insulin Resistance in Rats
}

\author{
Hasanpasha N Sholapur ${ }^{1 *}$, Basanagouda M Patil ${ }^{2}$ \\ 'Department of Pharmacognosy, KLE University's College of Pharmacy, Vidyanagar, Hubballi, Karnataka, INDIA. \\ ${ }^{2}$ Department of Pharmacology, KLE University's College of Pharmacy, Vidyanagar, Hubballi, Karnataka, INDIA.
}

\begin{abstract}
Objective: Alcoholic extract of the bark of Moringa oleifera Lam. (MO), (Moringaceae), has been experimentally evaluated previously for its insulin sensitizing potentials. In the quest to explore the possibility of the class of phytochemical(s) responsible for this experimental claim, the alcoholic extract was fractionated and evaluated for insulin sensitizing effect in rat model for insulin resistance. Methods: Alcoholic extract of MO was fractionated into, non-polar [petroleum ether (PEF)], moderately non-polar [ethyl acetate (EAF)] and polar [aqueous (AQF)] fractions. The fractions obtained were investigated for their insulin sensitizing properties in dexamethasone induced insulin resistance in rats. The bioactive fraction was analysed by spectroscopy for further characterization of phytochemical(s) present. Results: Acute treatment for $4 \mathrm{~h}$ with dexamethasone $11 \mathrm{mg} / \mathrm{kg}$ i.p.) in rats led to the development of impaired oral glucose tolerance. Treatment with pioglitazone and EAF abolished dexamethasone induced oral glucose intolerance (OGT). Dexamethasone $(1 \mathrm{mg} / \mathrm{kg}$ s.c., once daily for 11 d) administration led to the development of insulin resistance, characterised by fasting hyperglycemia, hyperinsulinemia, hypertriglyceridemia, impaired OGT and increased HOMA IR index. Treatments with EAF (140 mg/kg p.o.) and pioglitazone [PIO (10 mg/kg p.o.)] significantly prevented dexamethasone induced metabolic changes. Similarly, treatment with AQF (95 mg/kg p.o.) also significantly prevented metabolic changes
\end{abstract}

due to dexamethasone except impaired OGT. In contrast PEF (15 mg/kg p.o.) failed to prevent these metabolic changes except hypertriglyceridemia. Conclusion: The present study reveals that triterpenoid and the polyphenols (procyanidin) class of phytochemicals detected in EAF of alcoholic extract of $\mathrm{MO}$ bark may be responsible for the prevention of dexamethasoneinduced insulin resistance in rats.

Key words: Dexamethasone, Insulin resistance, Moringa oleifera, Oral glucose tolerance test, Serum triglyceride.

Key message: This is the first report which confirms and speculates the presence of polyphenols and triterpenoids respectively in EAF of $\mathrm{MO}$ which may be responsible for preventing the development of insulin resistance in rat model.

Correspondence :

Dr. Hasanpasha N. Sholapur, Department of Pharmacognosy, KLE University's College of Pharmacy, Vidyanagar, Hubballi-580 031, Karnataka, INDIA.

Phone: +91 836-2373174; Fax: +91 836-2371694

Email: hasanpashas@gmail.com; bmpatil59@hotmail.com

DOI: 10.5530/jyp.2017.9.81

\section{INTRODUCTION}

Diabetes, fourth leading causes of death worldwide is a cluster of hyperinsulinemia, dyslipidemia, glucose intolerance, obesity and hypertension. ${ }^{1}$ Insulin resistance, a prediabetic state of resistance towards the effects of insulin on its target tissues mainly in muscle, liver, and adipose tissue, is a central pathogenic feature of diabetes. ${ }^{2}$ Currently, PPAR $\gamma$ agonists are used as insulin sensitizers in the treatment of diabetes. ${ }^{3}$ Though, there are various techniques to manage diabetes and its complications, but still herbal formulations are the priority due to low treatment cost and lesser side effects. Around $80 \%$ of the world's population depends on traditional medicines derived from plants. Among the 21,000 medicinal plants used, 800 of them have been reported to be used in the treatment of diabetes worldwide. ${ }^{4}$ Phytochemicals reported to have antidiabetic effect from these medicinal plants include alkaloids, triterpenoids, steroids, flavonoids, phenolics, iridoids, guanidines etc., and these phytochemicals may also have potential beneficial effects on insulin resistance which may be investigated. Given that insulin resistance increases the risk of type 2 diabetes and cardiovascular diseases, modulatory effect on insulin resistance may be the important mechanism through which these phytoconstituents can offer protection. Hence identification of potentially effective class of phytochemicals for insulin resistance state represents an attractive and potentially effective approach to the problem.
Moringa oleifera Lam., (MO) syn., Moringa ptreygosperma Gaertn., (Family-Moringaceae) commonly known as horseradish tree or drumstick tree..$^{5}$ All parts of this plant are being employed for the treatment of various ailments in the indigenous system of medicine. Traditionally the bark is used as cardiac and circulatory stimulant. ${ }^{6}$ Experimental studies revealed, that the bark possess hypoglycaemic, antioxidant, cardioprotective effect and in our previous study we have reported the insulin sensitizing effect of the alcoholic extract of the bark. ${ }^{7}$ Various class of phytochemicals are reported in the bark which includes alkaloids (moringine and moringinine), ${ }^{8}$ glycosides (glucosinolate namely 4-(alpha-1rhamnopyranosyloxy)-benzylglucosinolate), ${ }^{9}$ tannins, triterpenoids, ${ }^{10}$ and polyphenols (procyanidins). ${ }^{11}$ In order to explore the possibility of insulin sensitization by any of the reported class of phytochemical(s) present in the alcoholic extract of the bark, ${ }^{7}$ the present study was designed to test the various fractions of alcoholic extract in dexamethasone-induced chronic and acute rat model for insulin resistance.

\section{MATERIALS AND METHODS}

\section{Chemicals}

Dexamethasone (Dexona) injection was purchased from Zydus Cadila, Ahmedabad, India. Pioglitazone maleate was obtained as a gift sample from Torrent Pharmaceutical Ltd, Ahmedabad, India. Plasma biochemical estimation kits like glucose, triglyceride and total cholesterol were purchased

This is an open access article distributed under the terms of the Creative Commons Attribution-NonCommercial-ShareAlike 4.0 License, which allows others to remix, tweak, and build upon the work non-commercially, as long as the author is credited and the new creations are licensed under the identical terms. 
form Erba Transasia Bio-Medicals Ltd, Baddi, Himachal Pradesh, India. Plasma insulin estimation kit was purchased form MP Biomedicals, LLC, Eschwege, Germany, (kit code no. CT Insulin, lot no. INK 1223) Instrument used was Gamma counter, ECIL.

\section{Plant material}

The fresh bark of MO was collected in the month of November \& December, from the local areas of Hubli-Dharward, Karnataka, India. The bark was authenticated by botanist Dr.Ganesh R. Hegde, Professor, P.G. Department of Botany, Karnatak University, Dharward, Karnataka, India and a voucher specimen bearing no. DOUN09017 is maintained in the herbarium of department of pharmacognosy of KLES College of pharmacy, Hubli, Karnataka, India.

\section{Preparation of extract and fractions}

The collected fresh bark of MO was dried and powdered coarsely. The bark coarse powder of $250 \mathrm{~g}$ was macerated at room temperature with $3 \times 1 \mathrm{~L}$ ethanol $80 \% \mathrm{v} / \mathrm{v}$. Following filtration, the combined alcoholic extract was concentrated in-vacuo below $40{ }^{\circ} \mathrm{C}$ and finally dried in desiccator.

The crude alcoholic extract was fractionated into non-polar [petroleum ether (PEF)], moderately non-polar [ethyl acetate (EAF)] and polar [aqueous (AQF)] fractions by reconstituting $10 \mathrm{~g}$ in $1000 \mathrm{ml}$ water and the solution was fractionated successively in a separating funnel with petroleum ether $(60-80)(3 \times 500 \mathrm{ml})$ and ethyl acetate $(3 \times 500 \mathrm{ml})$ followed by evaporation of organic solvent layers. Finally, the remaining aqueous layer was evaporated to dryness under reduced pressure.

\section{Preliminary phytochemical investigation ${ }^{12}$}

The fractions obtained were tested by qualitative chemical tests for the presence of phytoconstituents.

\section{HPTLC Analysis}

HPTLC analysis of the fractions were performed using precoated (silica gel $60 \mathrm{~F}_{254}$; $0.25 \mathrm{~mm}$ thickness; size 20 x $20 \mathrm{~cm}$; Merk, Darmstadt, Germany) TLC plates. Samples were prepared in methanol $(10 \mathrm{mg} / \mathrm{ml})$ and were applied on the TLC plate by a Desaga auto sampler (AS 30 Desaga, Sarstedt Gruppe, Germany). The plates were developed in a CAMAG twin trough developing chamber (CAMAG, Muttenz, Switzerland) using chloroform and methanol (85:15) as mobile phase followed by air-drying and spraying with $5 \%$ ethanolic phosphomolybdic acid, ${ }^{10} 10 \%$ ferric chloride and Liebermann-Burchard as detecting reagents on different plates respectively, which were developed similarly followed by heating the plates at $115^{\circ} \mathrm{C}$ for $5 \mathrm{~min}$. The $\mathrm{R}_{\mathrm{f}}$ values were determined by scanning the plates with densitometer (CD 60 Desaga, Sarstedt Gruppe, Germany) at $254 \mathrm{~nm}, 366 \mathrm{~nm}$ (before derivatization) and at $580 \mathrm{~nm}$ (after derivatization) using ProQuant 1.06 version software.

\section{Animal Experiment}

Male Wistar rats initially weighing 180 - $200 \mathrm{~g}$ were procured from the animal house of KLES College of pharmacy, Hubli, Karnataka, India. The rats were housed for $1 \mathrm{wk}$ for acclimatization at controlled room temperature $\left(22 \pm 2{ }^{\circ} \mathrm{C}\right)$, natural $12 \mathrm{~h}$ light: $12 \mathrm{~h}$ dark cycle, free access to standard laboratory chow and water. After $1 \mathrm{wk}$ of acclimatization, rats were randomly selected for different experimental groups. All the experimental procedures were carried out in accordance with committee for the purpose of control and supervision of experiments on animal (CPCSEA) guidelines. All the experimental protocols were reviewed and approved by Institutional Animal Ethical committee of KLES College of Pharmacy, Hubli, Karnataka, India.

\section{Dose preparation of dexamethasone and fractions of MO}

Dexamethasone (dexa) stock solution was prepared freshly in normal saline. ${ }^{13,14}$ All the fractions of alcoholic extract of MO bark and pioglitazone were separately suspended in vehicle $(1 \% \mathrm{w} / \mathrm{v}$ Tween 80$)$ to obtain the desired concentration and were administered orally.

\section{Experimental design}

Acute study

Twelve hours fasted rats were randomly divided into the six groups of six animals $(n=6)$ each and received the following treatment, Group I (Control): received gavage of vehicle $1 \mathrm{ml} / \mathrm{rat}$ and normal saline $0.1 \mathrm{ml} / \mathrm{rat}$ i.p., Group II (Dexa): received gavage of vehicle $1 \mathrm{ml} / \mathrm{rat}$ and treated with dexalmg/kg i.p., ${ }^{13}$ Group III (PEF+Dexa): received gavage of PEF 15 $\mathrm{mg} / \mathrm{kg}$ and dexa $1 \mathrm{mg} / \mathrm{kg}$ i.p., Group IV (EAF+Dexa): received gavage of EAF $140 \mathrm{mg} / \mathrm{kg}$ and dexa $1 \mathrm{mg} / \mathrm{kg}$ i.p., Group V (AQF+Dexa): received gavage of AQF $95 \mathrm{mg} / \mathrm{kg}$ and dexa $1 \mathrm{mg} / \mathrm{kg}$ i.p, Group VI (PIO+Dexa): received gavage of PIO $10 \mathrm{mg} / \mathrm{kg}$ and dexa $1 \mathrm{mg} / \mathrm{kg}$ i.p. ${ }^{15}$

Dexamethasone was administered $30 \mathrm{~min}$ after oral gavage of vehicle, fraction or PIO. After $4 \mathrm{~h}$ of dexamethasone administration animals were subjected to OGTT.

\section{Chronic Study}

Rats were randomly divided into six groups of six animals $(n=6)$ each and received the different treatments once daily for $11 \mathrm{~d}$ Group I (Control): received gavage of vehicle $1 \mathrm{ml} / \mathrm{rat}$ and normal saline $0.1 \mathrm{ml} /$ rat s.c., Group II (Dexa): received gavage of vehicle $1 \mathrm{ml} /$ rat and prestandardized dose of dexa $1 \mathrm{mg} / \mathrm{kg}$ s.c. ${ }^{14}$ Group III (PEF+Dexa) received gavage of PEF $15 \mathrm{mg} / \mathrm{kg}$ and dexa $1 \mathrm{mg} / \mathrm{kg}$ s.c., Group IV (EAF+Dexa): received gavage of EAF $140 \mathrm{mg} / \mathrm{kg}$ and dexa $1 \mathrm{mg} / \mathrm{kg}$ s.c., Group V (AQF+Dexa): received gavage of AQF $95 \mathrm{mg} / \mathrm{kg}$ and dexa $1 \mathrm{mg} / \mathrm{kg}$ s.c., Group VI (PIO+Dexa): received gavage of PIO $10 \mathrm{mg} / \mathrm{kg}^{15}$ and dexa 1 $\mathrm{mg} / \mathrm{kg}$ s.c. Dexamethasone was administered $30 \mathrm{~min}$ after oral gavage of vehicle or fraction.

At the end of experimental period animals were fasted for $12 \mathrm{~h}$ and subjected to oral glucose tolerance test (OGTT). Blood samples were collected by retro-orbital plexus puncture under light ether anesthesia. Zero-hour blood samples were used for estimation of blood glucose, triglyceride, cholesterol and insulin. The samples collected were centrifuged at $3000 \mathrm{rpm}$ for $20 \mathrm{~min}$ to separate out the serum which was then analysed. $^{7}$

\section{Oral glucose tolerance test ${ }^{7}$}

On completion of study period oral glucose tolerance test (OGTT) was performed to measure the plasma glucose in each group. Glucose solution at a dose of $2 \mathrm{gm} / \mathrm{kg}$ (body weight) was administered by gavage. Blood samples were collected from the retro orbital plexus prior to glucose load (0 min) and post-glucose load at 30, 60, and $120 \mathrm{~min}$.

\section{Biochemical estimation}

The concentration of plasma biochemical levels like glucose, triglyceride, total cholesterol and plasma insulin were measured by glucose oxidation method, ${ }^{16}$ GPO-POD enzymatic method, ${ }^{17}$ CHOD-POD enzymatic method ${ }^{18}$ and radioimmuno assay method ${ }^{19}$ respectively.

\section{Assessments of Insulin Resistance and Sensitivity}

The degree of insulin resistance was calculated by using Homeostasis Model Assessment (HOMA), ${ }^{20}$

$$
\text { HOMA }=(\text { fasting insulin } \times \text { fasting glucose }) / 405
$$




\section{Statistical analysis}

All the results are expressed as mean standard error mean ( \pm S.E.M). Statistical analysis was carried out using Student's t-test and One-way analysis of variance (ANOVA) followed by Dunnett's test for multiple comparisons using GraphPad Prism 5 software. P values of less than 0.05 were regarded as significant $(\mathrm{P}<0.05)$.

\section{Characterization of bioactive fraction}

Fourier Transform Infrared (FT-IR) spectroscopy: A FT-IR spectrum was recorded on IR 200 Nicolet IR spectrophotometer (Thermo Electron Corporation, MA U.S.A.). Spectra were taken in $\mathrm{KBr}$ pellets.

LC-MS analysis: EAF $100 \mathrm{mg}$ was dissolved in $10 \mathrm{ml}$ of methanol and was sonicated for $10 \mathrm{~min}$ at $30^{\circ} \mathrm{C}$ in the ultrasonic bath. The sample was filtered through a $0.45-\mu \mathrm{m}$ PVDF filter (Himedia labs. Pvt. Ltd., Mumbai, India) and was further used. Chromatography separation was performed using Surveyor Plus (Thermo Fisher Scientific, California, USA) HPLC system coupled to an MS analyser, LCQ Deca XP Max ion trap (Thermo finnigan, San Jose, CA, U.S.A.) with ESI interface using Xcalibur version 1.2 software for system control.

Sample was separated on $3 \mu \mathrm{m}$ Dionex bonded silica $\mathrm{C}_{18}$ column (150 $\times 4.6 \mathrm{~mm}$ : Acclaim 120, Thermo Fisher Scientific, California, USA). A binary gradient elution was applied (solvent A, $0.1 \%$ formic acid in water and solvent $\mathrm{B}$, methanol), ${ }^{16}$ flow rate was set to $0.5 \mathrm{ml} / \mathrm{min}$ and injection volume was $10 \mu \mathrm{l}$.

All the MS-MS analysis was carried out in the negative mode $[\mathrm{M}-\mathrm{H}]^{-1}$ under the following optimized conditions: spray voltage, $4.49 \mathrm{KV}$; capillary voltage, $19 \mathrm{~V}$; capillary temperature, $350^{\circ} \mathrm{C}$; sheath gas $\left(\mathrm{N}_{2}\right), 65$ arbitrary units; auxiliary gas $\left(\mathrm{N}_{2}\right), 10$ arbitrary units; full scan spectra were recorded within the $\mathrm{m} / \mathrm{z}$ range of $100-1000$; Collision energy: $35 \%$.

\section{RESULTS}

\section{Preparation of extract and fractions}

Three fractions were obtained viz., petroleum ether fraction (PEF) (yield $0.6 \mathrm{~g}, 6 \%$ ), ethyl acetate fraction (EAF) (yield $5.6 \mathrm{~g}, 56 \%$ ) and aqueous fraction (AQF) (yield 3.8g, $38 \%$ ).

\section{Preliminary phytochemical investigation}

Preliminary phytochemical studies exhibited the presence of steroids in PEF; triterpenoids and phenols in EAF; carbohydrates and glycosides in $\mathrm{AQF}$ respectively.

\section{HPTLC Analysis}

The HPTLC analysis of fractions revealed their finger print profiles. Petroleum ether fraction resolved 5 spots with $\mathrm{Rf}$ values $0.17,0.20,0.34$, 0.56 and 0.67 ; ethyl acetate fraction resolved 7 spots with $\mathrm{Rf}$ values 0.25 , $0.34,0.41,0.57,0.65,0.71$ and 0.84 ; the aqueous fraction resolved 5 spots with Rf values $0.14,0.39,0.42,0.54$ and 0.59 . Appearance of grey (with $10 \% \mathrm{fecl} 3$ reagent) or blue (LB reagent) spots was considered as positive evidence for the presence of phenols and triterpenes respectively ${ }^{21}$ (Figure 1).

\section{Animal Experiment Acute study}

Glucose intolerance developed after acute treatment of rats with dexamethasone (Control AUC 9923 \pm 441.3 vs Dexa AUC 12650 \pm 90.78 , $\mathrm{P}<0.001$ ) was significantly prevented in EAF treated (Dexa+EAF AUC 10284 $\pm 239.3, \mathrm{P}<0.001$ ) and PIO treated (Dexa+PIO AUC 9845 \pm 311.1 , $\mathrm{P}<0.001)$ rats. In contrast, $\mathrm{PEF}$ treatment further aggravated the dexamethasone induced glucose intolerance (Dexa+PEF AUC 15788 \pm 527.1 , $\mathrm{P}<0.001$ ). AQF treatment had no effect on this parameter (Figure 2).

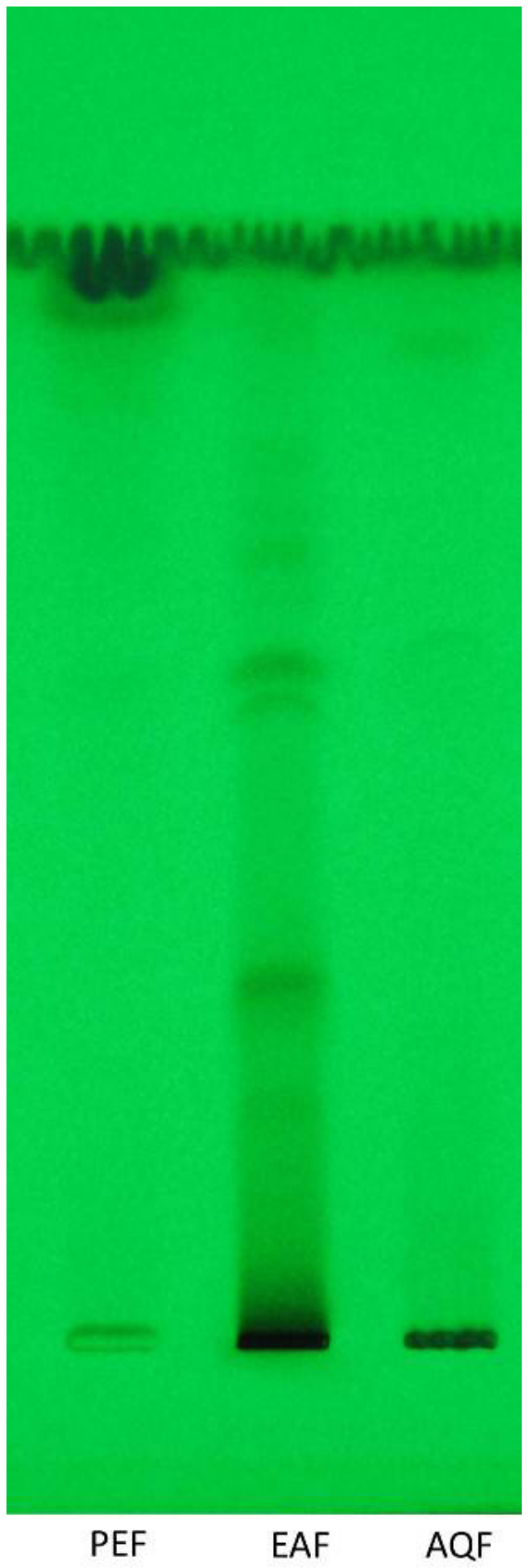

Figure 1: HPTLC chromatogram of PEF, EAF and AQF at UV 254nm.

\section{Chronic study}

As shown in Table 1, initial body weights of rats in all the groups were similar, dexamethasone treated rats lost the body weight significantly $(\mathrm{P}<0.001)$ compared to control rats. Treatment with PEF, EAF, AQF and PIO did not prevent the loss in body weight due to dexamethasone. Administration of dexamethasone showed significant increase in levels of fasting glucose $(\mathrm{P}<0.01)$, triglyceride $(\mathrm{P}<0.001)$, insulin $(\mathrm{P}<0.01)$ and HOMA IR $(\mathrm{P}<0.001)$. Treatment with EAF, AQF and PIO significantly $(\mathrm{P}<0.001)$ reduced fasting hyperglycemia, hypertriglyceridemia, hyperinsulinemia, HOMA IR and fasting hyperglycemia (EAF $\mathrm{P}<0.05$; AQF $\mathrm{P}<0.05$ and $\mathrm{PIO} \mathrm{P}<0.001)$ induced by dexamethasone, whereas, treatment with PEF did not alter these metabolic changes. Dexamethasone, all the fractions and PIO tested did not show any effect on total cholesterol levels. 
Table 1: Effect of PEF, EAF, AQF and PIO on body weight, triglyceride, cholesterol, glucose and insulin levels in dexamethasone treated rats (Chronic study).

\begin{tabular}{|c|c|c|c|c|c|c|c|}
\hline \multirow{2}{*}{ Treatment groups } & \multicolumn{2}{|c|}{ Body Weight } & \multirow{2}{*}{$\begin{array}{l}\text { Triglyceride } \\
\mathrm{mg} / \mathrm{dl}\end{array}$} & \multirow{2}{*}{$\begin{array}{c}\text { Cholesterol } \\
\mathrm{mg} / \mathrm{dl}\end{array}$} & \multirow{2}{*}{$\begin{array}{c}\text { Glucose } \\
\mathrm{mg} / \mathrm{dl}\end{array}$} & \multirow{2}{*}{$\begin{array}{l}\text { Insulin } \\
\mu \mathrm{U} / \mathrm{ml}\end{array}$} & \multirow{2}{*}{ HOMA } \\
\hline & Initial & Final & & & & & \\
\hline Control & $190.0 \pm 3.000$ & $208.0 \pm 4.066$ & $56.14 \pm 2.122$ & $64.85 \pm 1.327$ & $89.18 \pm 5.130$ & $52.83 \pm 4.277$ & $11.82 \pm 1.539$ \\
\hline Dexa & $198.7 \pm 0.843$ & $157.2^{\mathrm{c}} \pm 2.725$ & $297.8^{\mathrm{c}} \pm 12.29$ & $53.34 \pm 9.602$ & $109.6^{\mathrm{b}} \pm 0.680$ & $78.00^{\mathrm{b}} \pm 3.890$ & $21.11^{c} \pm 1.076$ \\
\hline Dexa +PEF & $189.2 \pm 2.442$ & $148.0 \pm 4.726$ & $89.83^{z} \pm 2.748$ & $39.65 \pm 2.782$ & $100.0 \pm 9.148$ & $63.50 \pm 5.233$ & $15.84 \pm 2.199$ \\
\hline Dexa +EAF & $189.0 \pm 3.688$ & $152.0 \pm 4.066$ & $74.98^{z} \pm 5.596$ & $39.61 \pm 3.586$ & $92.83^{x} \pm 7.441$ & $42.67^{z} \pm 6.020$ & $10.05^{z} \pm 1.897$ \\
\hline Dexa+AQF & $196.7 \pm 1.256$ & $164.2 \pm 5.121$ & $114.2^{z} \pm 12.92$ & $49.37 \pm 3.574$ & $92.11^{x} \pm 4.688$ & $43.00^{z} \pm 2.944$ & $9.740^{z} \pm 0.716$ \\
\hline Dexa + PIO & $196.7 \pm 1.202$ & $152.0 \pm 2.955$ & $70.62^{z} \pm 3.433$ & $40.16 \pm 3.448$ & $89.79^{z} \pm 2.909$ & $40.33^{z} \pm 3.007$ & $8.89^{\mathrm{z}} \pm 0.727$ \\
\hline
\end{tabular}

Values are means \pm SEM; Dexamethasone $1 \mathrm{mg} / \mathrm{kg}$ (Dexa); Dexamethasone+petroleum ether fraction $15 \mathrm{mg} / \mathrm{kg}$ (Dexa+PEF), Dexamethasone+ethyl acetate fraction $140 \mathrm{mg} / \mathrm{kg}$ (Dexa+EAF), Dexamethasone+aqueous fraction $95 \mathrm{mg} / \mathrm{kg}$ (Dexa+AQF), Dexamethasone+pioglitazone $10 \mathrm{mg} / \mathrm{kg}$ (Dexa+PIO).

${ }^{b} \mathrm{P}<0.01,{ }^{c} \mathrm{P}<0.001$ Compared with Control rats.

${ }^{x} \mathrm{P}<0.05,{ }^{z} \mathrm{P}<0.001$ Compared with Dexamethasone rats.
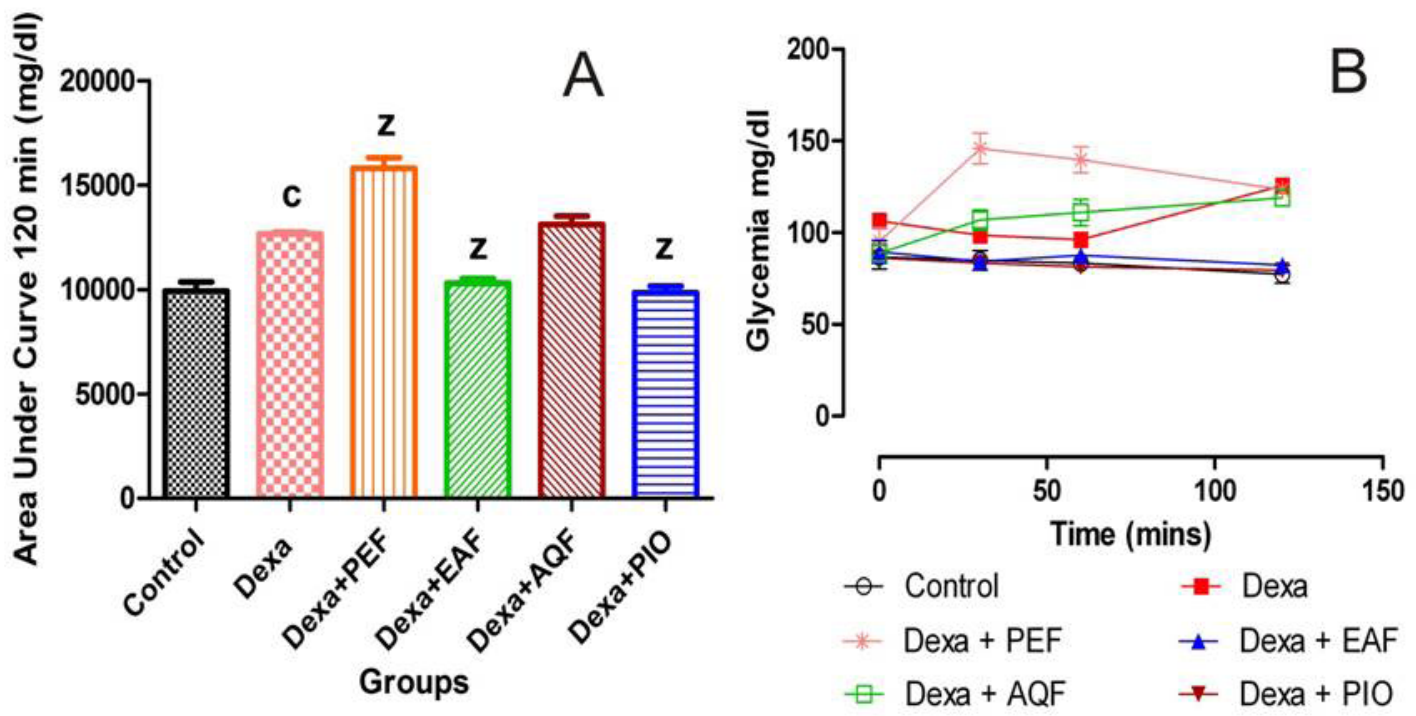

Values are means $\pm \mathrm{SEM}$; Area under curve (AUC); Dexamethasone $1 \mathrm{mg} / \mathrm{kg}$ (Dexa);

Dexamethasone+Petroleum ether fraction $15 \mathrm{mg} / \mathrm{kg}$ (Dexa+PEF), Dexamethasone+Ethyl acetate fraction $140 \mathrm{mg} / \mathrm{kg}$ (Dexa+EAF), Dexamethasone+Aqueous fraction $95 \mathrm{mg} / \mathrm{kg}$ (Dexa+AQF),

Dexamethasone+pioglitazone $10 \mathrm{mg} / \mathrm{kg}$ (Dexa+PIO).

c $P<0.001$ vs Control rats.

${ }^{z} P<0.001$ vs Dexamethasone rats.

Figure 2: (A) Total area under curve of OGTT values from zero to $120 \mathrm{~min}$, from control, Dexa, Dexa+PEF, Dexa+EAF, Dexa+AQF, Dexa+PIO groups and (B) Glycemia levels after oral glucose charge in tolerance test (Acute study).

Administration of dexamethasone led to the development of impaired glucose tolerance as indicated by significant increase in the sum of glucose levels during the OGTT in this group compared to control (Control AUC $10310 \pm 590.2$ vs Dexa AUC $13020 \pm 222.6, \mathrm{P}<0.01$ ). Treatment with PIO and EAF prevented dexamethasone-induced impaired glucose tolerance as indicated by significant reduction in sum of glucose levels during OGTT compared to dexamethasone group (Dexa+PIO AUC 10149 \pm 139.7, P<0.001; Dexa+EAF AUC 10529 \pm 314.5 , $\mathrm{P}<0.001)$. Treatment with AQF had no effect on dexamethasone-induced glucose intolerance (Dexa+AQF AUC 12997 \pm 586.3 ). Further, treatment with PEF augmented significantly the effect of dexamethasone on the rise in sum of glucose levels during OGTT compared to dexamethasone group (Dexa+PEF AUC 16108 $\pm 597.3, \mathrm{P}<0.001$ ) (Figure 3).

\section{Characterization of bioactive fraction}

FT-IR spectroscopy was used to augment the findings of preliminary phytochemical investigations of bioactive EAF. The EAF spectra showed absorption at 3354.90 (O-H stretching 3400-3100), ${ }^{22} 2922.99$ (asymmetric -C-H stretching 3000-2900), ${ }^{23} 1613.86$ (-C=C- aromatic stretching), ${ }^{22}$ 1510.09 (-C $=\mathrm{C}-)^{23}, 1266.01(\mathrm{C}-\mathrm{O}$ stretching $1300-1000),{ }^{23} 807.24$ and 

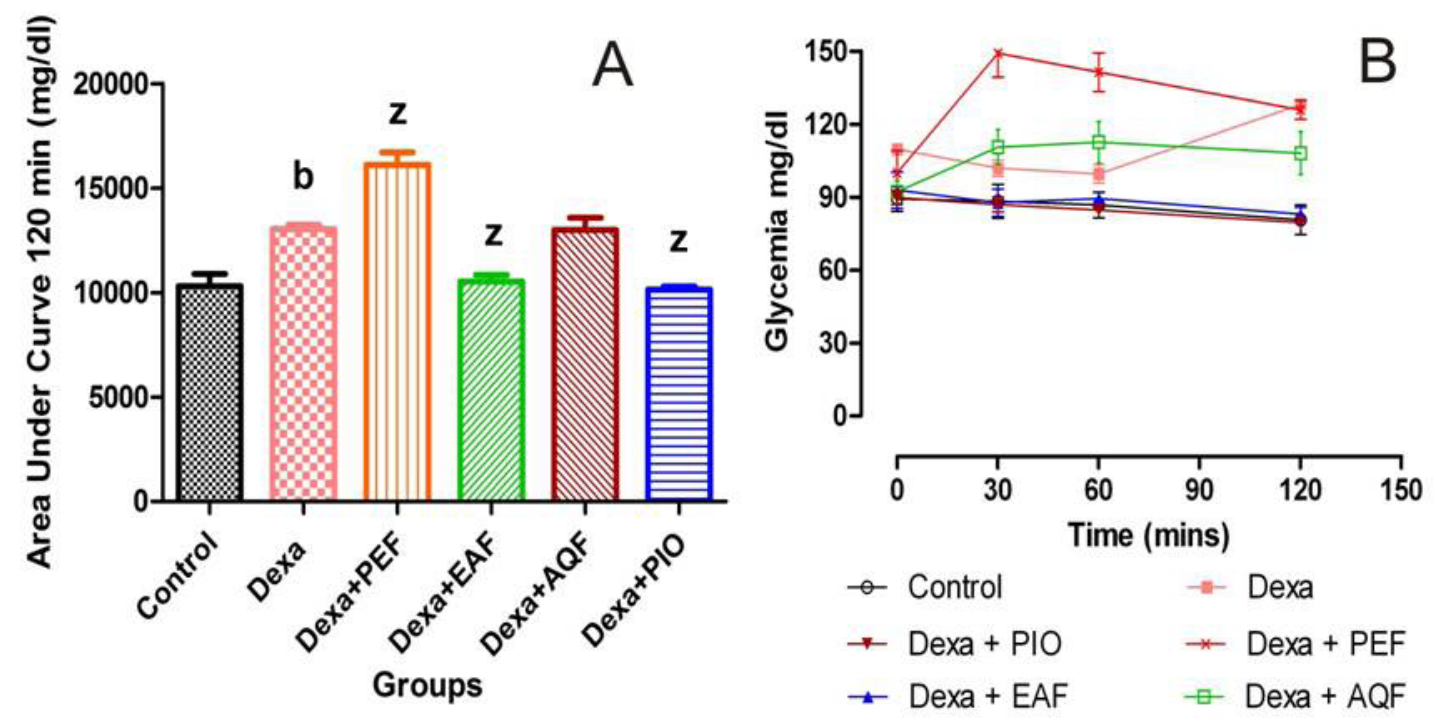

Values are means $\pm \mathrm{SEM}$; Area under curve (AUC); Dexamethasone $1 \mathrm{mg} / \mathrm{kg}$ (Dexa);

Dexamethasone+Petroleum ether fraction $15 \mathrm{mg} / \mathrm{kg}$ (Dexa+PEF), Dexamethasone+Ethyl acetate fraction $140 \mathrm{mg} / \mathrm{kg}$ (Dexa+EAF), Dexamethasone+Aqueous fraction $95 \mathrm{mg} / \mathrm{kg}$ (Dexa+AQF), Dexamethasone+pioglitazone $10 \mathrm{mg} / \mathrm{kg}$ (Dexa+PIO).

${ }^{\mathbf{b}} P<0.01$ vs Control rats.

${ }^{z} P<0.001$ vs Dexamethasone rats.

Figure 3: (A) Total area under curve of OGTT values from zero to $120 \mathrm{~min}$, from control, Dexa, Dexa+PEF, Dexa+EAF, Dexa+AQF, Dexa+PIO groups and (B) Glycemia levels after oral glucose charge in tolerance test (Chronic study).

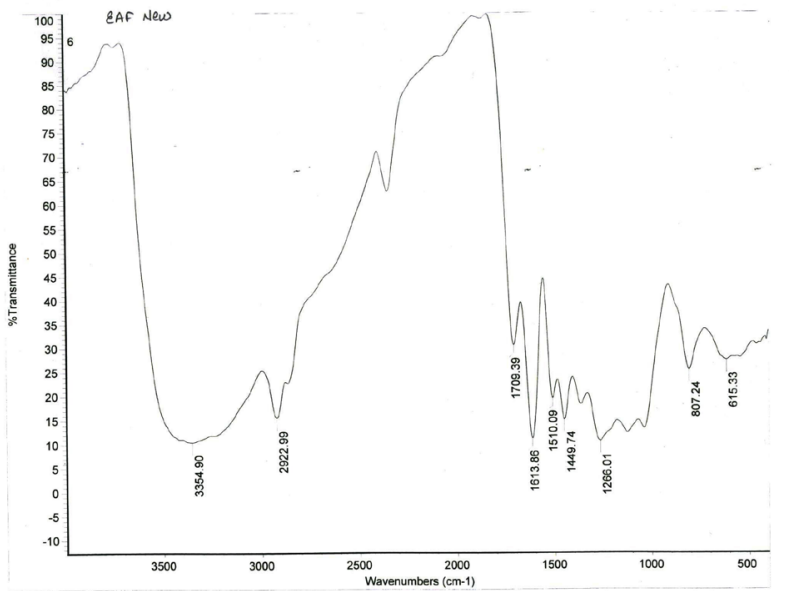

Figure 4: FT IR Spectrum of EAF.

615.33 which are characteristic for polyphenol (procyanidin type). ${ }^{22}$ The other absorptions at $1449.74\left(\mathrm{C}-\mathrm{H} \text { bending cyclic }(\mathrm{CH} 2)_{\mathrm{n}}\right)^{23}$ and 1709.39 $(\mathrm{C}=\mathrm{O} \text { characteristic for esters } 1710-1690)^{23}$ may be speculated due to the presence of triterpenes (Figure 4).

The LC MS and MS/MS (negative ion mode) analysis of bioactive EAF reveals that, some of the fragmentation values like $\mathrm{m} / \mathrm{z} 576.98$ and $\mathrm{m} / \mathrm{z}$ 288.93 are in accordance with the reported fragmentation values ${ }^{24}$ for deprotonated molecule of (epi)catechin dimer and (epi)catechin monomer

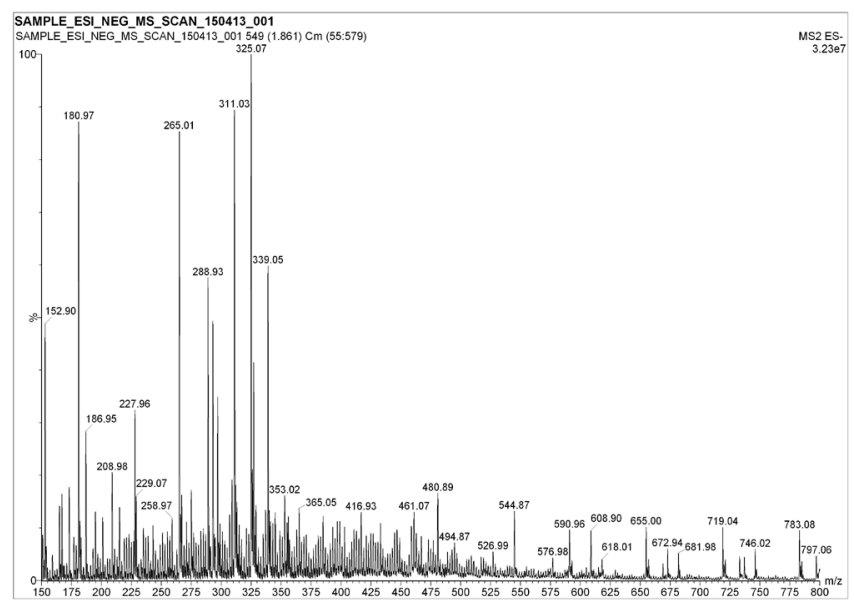

Figure 5: LC MS Spectrum of EAF.

of a polyphenol (procyanidin type) ${ }^{11}$ indicating its presence as one of the phytochemical in the ethyl acetate fraction (Figure 5).

\section{DISCUSSION}

The results of the current study demonstrate that EAF of MO prevents whole body IR, whereas, AQF of MO prevents hepatic IR induced by dexamethasone.

Our previous study has demonstrated that alcoholic extract of MO bark prevented IR at the dose of $250 \mathrm{mg} / \mathrm{kg}$. ${ }^{7}$ The percentage yield of PEF, EAF 
and $\mathrm{AQF}$ obtained from alcoholic extract in the present study were $6 \%$, $56 \%$ and $38 \%$ respectively. Based on these yield a quantity proportional to $250 \mathrm{mg}$ was calculated for each fraction and employed as test dose.

At the tissue level IR is observed in skeletal muscle, adipose tissue and liver. Skeletal muscles are generally considered as major peripheral tissue responsible for disposal of blood glucose and impaired glucose tolerance is characteristic of peripheral IR whereas hepatic IR is generally characterized by fasting hyperglycemia and hyperinsulinemia. ${ }^{25}$ Further, during IR antilipolytic effects of insulin is reduced which eventually leads to increased synthesis of TG from live. ${ }^{26}$ In the present study, rats treated for 11 days developed whole body IR characterized by fasting hyperglycemia, hyperinsulinemia, hypertriglyceridemia and impaired oral glucose tolerance. These results are consistent with previous report. ${ }^{27}$ In these rats EAF was effective in preventing both impaired oral glucose tolerance and fasting biochemical changes of IR, whereas, AQF was effective in abolishing only fasting biochemical changes of IR. These observations suggest that EAF was able to prevent dexamethasone induced IR in all target tissues of insulin, whereas, $\mathrm{AQF}$ was effective only at hepatic tissue. By employing euglycemic- hyperinsulinemia clamp study in rats it is reported that single dose of daxamethasone induces IR. ${ }^{14}$ Consistent with this report in the present study rats treated with single dose of dexamethasone developed IR as indicated by impaired oral glucose tolerance observed in these rats. Using this, model we tested the acute effect of different fractions on dexamethasone induced altered glucose uptake by peripheral tissues. Interestingly, only EAF could abolish dexamethasone induced impaired oral glucose tolerance, whereas PEF and AQF failed to modify this effect. These findings further support our observations made in chronic study that, EAF but not AQF of MO is effective in overcoming peripheral IR due to dexamethasone.

Qualitative, chemical identification tests and HPTLC analysis revealed the presence of polyphenols and triterpenoids in EAF. Further characterization of the bioactive EAF by FT-IR and LC MSn, analysis confirmed the presence of polyphenols (procyanidin) as one of the phytochemical present in the EAF on comparison with the previous literature values. Polyphenols and triterpenoids are some of the important phytochemicals reported to increase insulin sensitivity in different models of IR which supports our findings in this study. ${ }^{28,29}$ Similarly, presence of glycosides in AQF may be responsible for abolishing IR in hepatic tissue observed in present study, since glycosides are reported to possess insulin sensitizing effects. ${ }^{30}$

\section{CONCLUSION}

This is the first report which confirms and speculates the presence of polyphenols and triterpenoids respectively in EAF of MO which may be responsible for preventing the development of IR in rat model. Isolation and pharmacological evaluation of phytoconstituents form these fractions may further confirm our finding.

\section{ACKNOWLEDGEMENT}

The authors are thankful to KLE University, Belgaum for providing the facilities to carry out the research

\section{CONFLICT OF INTEREST}

Authors do not have any conflict of interest.

\section{REFERENCES}

1. Murugesh K, Yeligar V, Dash DK, Sengupta $P$, Maiti BC, et al. Antidiabetic, antioxidant and antihyperlipidemic status of Heliotropium zeylanicum extract on streptozotocin-induced diabetes in rats. Biological and Pharmaceutical Bulletin. 2006;29(11):2202-5. https://doi.org/10.1248/bpb.29.2202; PMid:17077515.

2. Reaven GM. Role of insulin resistance in human disease. Diabetes.
1988;37(12):1595-607. https://doi.org/10.2337/diabetes.37.12.1595; https://doi. org/10.2337/diab.37.12.1595; PMid:3056758.

3. Singh C, Jain KA, Kumar C, Agarwal K. Design and in vitro Evaluation of Mucoadhesive Microcapsules of Pioglitazone. JYoung Pharm 2009; 1 (3) :195-198. https://doi.org/10.4103/0975-1483.57063.

4. Modak M, Dixit P, Londhe J, Ghaskadbi S, Devasagayam TP. Recent Advances in Indian Herbal Drug Research Guest Editor: Thomas Paul Asir Devasagayam Indian Herbs and Herbal Drugs Used for the Treatment of Diabetes. Journal of clinical biochemistry and nutrition. 2007;40(3):163-73. https://doi.org/10.3164/ jcbn.40.163; PMid:18398493 PMCid:PMC2275761.

5. Magadi RG. Botanical and vernacular names of south Indian plants. Divya Chandra prakashana, Bangalore, India; 2001: 282-83.

6. Anwar F, Latif S, Ashraf M, Gilani AH. Moringa oleifera: a food plant with multiple medicinal uses. Phytotherapy research. 2007;21(1):17-25. https://doi. org/10.1002/ptr.2023; PMid: 17089328.

7. Sholapur HN, Patil BM. Effect of Moringa oleifera bark extracts on dexamethasone-induced insulin resistance in rats. Drug research. 2013;63(10):527-31. https://doi.org/10.1055/s-0033-1347238; PMid: 23780503.

8. Anonymous. The wealth of India, A Dictionary of Indian Raw Materials and Industrial Products, Raw materials, Vol VI, L-M. National institute of science communication and Information resources, council of scientific and industrial research, New Delhi; 2003: 425-29.

9. Bennett RN, Mellon FA, Foidl N, Pratt JH, Dupont MS, et al. Profiling glucosinolates and phenolics in vegetative and reproductive tissues of the multipurpose trees Moringa oleifera L.(horseradish tree) and Moringa stenopetala L. Journal of Agricultural and Food Chemistry. 2003;51(12):3546-53. https://doi. org/10.1021/jf0211480; PMid:12769522.

10. Sholapur HP, Patil BM. Pharmacognostic and phytochemical investigations on the bark of Moringa oleifera Lam.

11. Atawodi SE, Atawodi JC, Idakwo GA, Pfundstein B, Haubner R, Wurtele G, Bartsch $\mathrm{H}$, Owen RW. Evaluation of the polyphenol content and antioxidant properties of methanol extracts of the leaves, stem, and root barks of Moringa oleifera Lam. Journal of Medicinal Food. 2010;13(3):710-6. https://doi. org/10.1089/jmf.2009.0057; PMid:20521992.

12. Kokate CK. Pratical Pharmacognosy. Vallabh Prakan. New Delhi. 1994 PMid:7932175

13. Burén J, LaiYC, Lundgren M, Eriksson JW, Jensen J. Insulin action and signalling in fat and muscle from dexamethasone-treated rats. Archives of biochemistry and biophysics. 2008;474(1):91-101. https://doi.org/10.1016/j.abb.2008.02.034; PMid:18328801.

14. Qi D, Pulinilkunnil T, An D, Ghosh S, Abrahani A, Pospisilik JA, Brownsey R, Wambolt $R$, Allard $M$, Rodrigues $B$. Single-dose dexamethasone induces whole-body insulin resistance and alters both cardiac fatty acid and carbohydrate metabolism. Diabetes. 2004;53(7):1790-7. https://doi.org/10.2337/diabetes.53.7.1790 PMid:15220203.

15. Behera JP, Ramani YR, Prusty I, Rohit SS. Antioxidant Effect of Aqueous Extract of Triticum aestivum Grass on Insulin Resistance models in Wista Albino Rats. Free Radicals and Antioxidants. 2015;5(2):43. https://doi. org/10.5530/fra.2015.2.1.

16. Barham D, Trinder P. An improved colour reagent for the determination of blood glucose by the oxidase system. Analyst. 1972;97(1151):142-5. https://doi. org/10.1039/an9729700142; PMid:5037807.

17. Bucolo G, David H. Quantitative determination of serum triglycerides by the use of enzymes. Clinical chemistry. 1973;19(5):476-82. PMid:4703655

18. Allain CC, Poon LS, Chan CS, Richmond WF, Fu PC. Enzymatic determination of total serum cholesterol. Clinical chemistry. 1974;20(4):470-5. PMid:4818200

19. Bell ET, Loraine JA, editors. Hormone Assays and Their Clinical Application. Churchill Livingstone; 1976.

20. Katz A, Nambi SS, Mather K, Baron AD, Follmann DA, Sullivan G, et al. Quantitative insulin sensitivity check index: a simple, accurate method for assessing insulin sensitivity in humans. The Journal of Clinical Endocrinology \& Metabolism. 2000;85(7):2402-10. https://doi.org/10.1210/jcem.85.7.6661; PMid:10902785.

21. Stahl E. Thin layer chromatography, A laboratory hand book, 2nd ed. Springerverlag, Heidelberg, Germany; 1990: 855-87.

22. Maoela MS, Arotiba OA, Baker PG, Mabusela WT, Jahed N, Songa EA, Iwuoha El. Electroanalytical determination of catechin flavonoid in ethyl acetate extracts of medicinal plants. Int. J. Electrochem. Sci. 2009;4:1497-510.

23. Stuart BH. Infrared Spectroscopy: Fundamentals and applications. John Wiley and sons Ltd, West Sussex, England; 2004: 71-140. https://doi. org/10.1002/0470011149.

24. Wollgast J, Pallaroni L, Agazzi ME, Anklam E. Analysis of procyanidins in chocolate by reversed-phase high-performance liquid chromatography with electrospray ionisation mass spectrometric and tandem mass spectrometric detection. Journal of Chromatography A. 2001;926(1):211-20. https://doi.org/10.1016/ S0021-9673(01)00994-3.

25. Nathan DM, Davidson MB, Defronzo RA, Heine RJ, Henry RR, Pratley R, et al Impaired fasting glucose and impaired glucose tolerance. Diabetes Care 2007; 30 (3): 753-59. https://doi.org/10.2337/dc07-9920; PMid:17327355.

26. De Fronzo RA. Pathogenesis of type 2 diabetes mellitus. Med Clin N Am 2004; 
88: 787-835. https://doi.org/10.1016/j.mcna.2004.04.013; PMid:15308380.

27. Severino C, Brizzi P, Solinas A, Secchi G, Maioli M, Tonolo G. Low-dose dexamethasone in the rat: a model to study insulin resistance. American Journa of Physiology-Endocrinology and Metabolism. 2002;283(2):E367-73. https://doi. org/10.1152/ajpendo.00185.2001; PMid:12110544.

28. Eid HM, Nachar A, Thong F, Sweeney G, Haddad PS. The molecular basis of the antidiabetic action of quercetin in cultured skeletal muscle cells and hepatocytes. Pharmacognosy magazine. 2015;11(41):74. https://doi.org/10.4103/09731296.149708; PMid:25709214 PMCid:PMC4329636.
29. Guo T, Zhu L, Tan J, Zhou X, Xiao L, Liu X, Wang B. Promoting effect of triterpenoid compound from Agrimonia pilosa Ledeb on preadipocytes differentiation via up-regulation of PPARy expression. Pharmacognosy magazine. 2015;11(41):219. https://doi.org/10.4103/0973-1296.149741; PMid:25709235 PMCid:PMC4329626.

30. Rathod N, Raghuveer I, Chitme HR, Ramesh C. Prevention of high-fructose diet induced insulin resistance by Nyctanthes arbortristis and Calotropis gigantea in rats. Pharmacognosy magazine. 2009;5(19):58.

Article History: Submission Date : 02-03-2017; Revised Date : 16-04-2017; Acceptance Date : 04-05-2017.

Cite this article: Effect of Fractions of Alcoholic Extract of Moringa oleifera lam. Bark on Dexamethasone induced Insulin Resistance in Rats. Sholapur HN, Patil BM. J Young Pharm. 2017;9(3):410-6. 